\title{
Ensuring the Required Accuracy of Initial Alignment of GNSS Attitude Navigation Receivers on User Equipment
}

\author{
Anatoly A. Frolov* \\ Russian Metrological Institute \\ of Technical Physics and Radio Engineering \\ Mendeleevo, Moscow region, 141570, Russia
}

Received 25.06.2018, received in revised form 13.07.2018, accepted 14.07.2018

The research represents the method of initial alignment of attitude navigation receivers that allows ensuring the required accuracy of initial alignment of attitude navigation receivers (ANR) on the customer's objects.

Keywords: attitude navigation receiver, initial alignment, accuracy.

Citation: Frolov A.A. Ensuring the required accuracy of initial alignment of GNSS attitude navigation receivers on user equipment, J. Sib. Fed. Univ. Eng. technol., 2019, 12(5), 555-560. DOI: 10.17516/1999-494X-0076.

\section{Обеспечение требуемой точности начальной выставки угломерной навигационной аппаратуры ГНСС на объектах потребителей}

\begin{abstract}
А.А. Фролов
Всероссийский научно-исследовательский институт физико-технических и радиотехнических измерений Россия, 141570, Московская область, Менделеево
\end{abstract}

Предложен метод начальной выставки угломерной навигационной аппаратуры космических навигационных систем (УНАП), позволяющий обеспечить погрешность начальной выставки УНАП на объектах потребителей.

Ключевые слова: угломерная аппаратура, начальная выставка, погрешность.

(C) Siberian Federal University. All rights reserved

* Corresponding author E-mail address: frolov aa@vniiftri.ru 


\section{Introduction}

Nowadays the most popular means of providing the customer with the attitude orientation information is inertial navigation system (INS). Independent functioning is an important operating property of INS. INS has been used for more than 50 years that is why there are wide-ranging methodic and technical instruments of testing, implementation (initial alignment) and periodic control of precise characteristics [1-4].

However recently INS is not always able to meet even increasing demands according to:

- time of the output of true measuring information about attitude orientation after voltage supply;

- providing the necessary accuracy within long intervals under condition of intensive maneuvering.

This fact increases the customers interest towards the mode of definition of attitude orientation according to GLONASS global navigation satellite system (GNSS) navigation satellites (NS) signals and other satellite radio navigation systems (SRNS) as well as complex INS / SRNS mode [5, 6]. In order to use these modes it is necessary that navigation receiver has several spaced antennas receiving NS signals [7]. This mode implementation provides definition of the customer positioning not as a material point but as a 3-dimensional object.

Thus, attitude navigation receivers tend to be used more and more often in cases when one needs any information on attitude orientation.

The present methods of attitude navigation receivers initial alignment on the customers' objects are based on the analytical interconnection of measuring axis of attitude navigation receivers (ANR) (Fig. 1) and construction axis of the ANR locating object (calculating of systematic corrections $\Delta_{1}, \Delta_{2}$, $\Delta_{3}$ ) (Fig. 2).
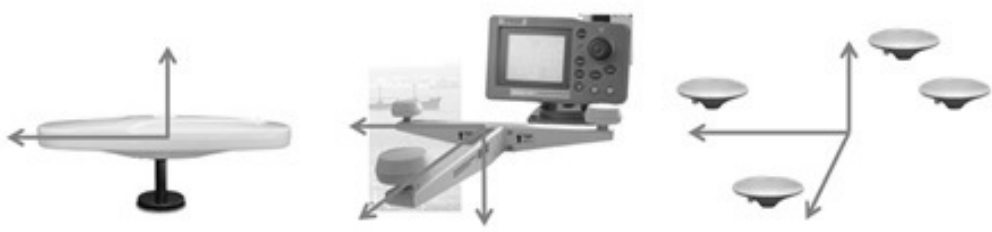

Fig. 1. Measuring axes of two, three and four antennas of ANR

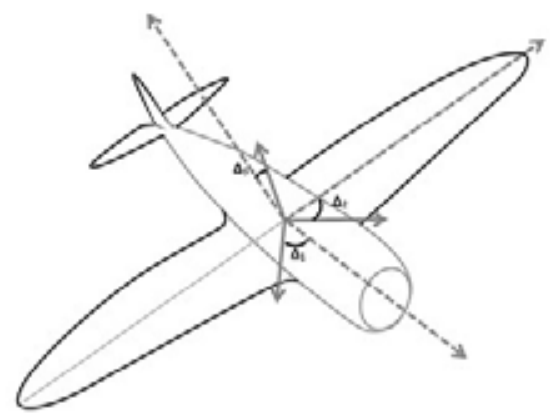

Fig. 2. Initial alignment of ANR 
The measuring results of ANR are averaged within the given time interval and the corrections to the values of attitude orientation angles are calculated. Depending on normalized values of ANR bias time interval of the ANR measuring results averaging differs from several minutes to several hours. It is explained by the fact that ANR measuring results contain slowly changing error component of prior unknown period associated with multipath NS signals propagation.

\section{Problem definition}

For ANR with the error (according to probability level 0,95 ) of attitude orientation measuring by antenna system 3' for course angle and 4' for roll and pitch angles (for the distance between antenna modules of ANR antenna system not more than $2 \mathrm{~m}$ ) the averaging interval of the results measuring amounts to $10 \mathrm{~h}$, for ANR with the error (according to probability level 0,95 ) of attitude orientation measuring by antenna system 6 ' for course angle and 8 ' for roll and pitch angles (for the distance between antenna modules of ANR antenna system not more than $2 \mathrm{~m}$ ) the averaging interval of the results measuring amounts to $5 \mathrm{~h}$.

It is better to reduce the time of initial alignments in case conducting ANR initial alignments on site for the large amount of equipment. This fact is explained by the analysis of ANR measurements for the presence in the measured values a slowly varying component of the error as well as the period determination of a slowly varying component of the error.

\section{Theory}

The analysis of the presence in the measured values a slowly varying component of the error is performed by comparing of the average values of measured parts of the sample according to Student's $t$-criterion. The algorithm step (minimum number of measurements) is prior determined for any $v \leq 1$, calculated with Formula (1):

$$
v_{i}=\left(\max \left(\mathrm{M}_{l_{i}}-\sum \mathrm{M}_{l_{i}}\right)-\min \left(\mathrm{M}_{l_{i}}-\sum \mathrm{M}_{l_{i}}\right)\right) \text {, }
$$

where $\mathrm{M}_{\mathrm{li}}$ - arithmetic mean of i-sample part with length 1 .

Fig. 3 describes the calculation of an algorithm step for one of ANR modifications.

As one can see from Fig. 3 the algorithm step for pitch and roll angles equals to $2000 \mathrm{~s}$, for course angle $-1000 \mathrm{~s}$.

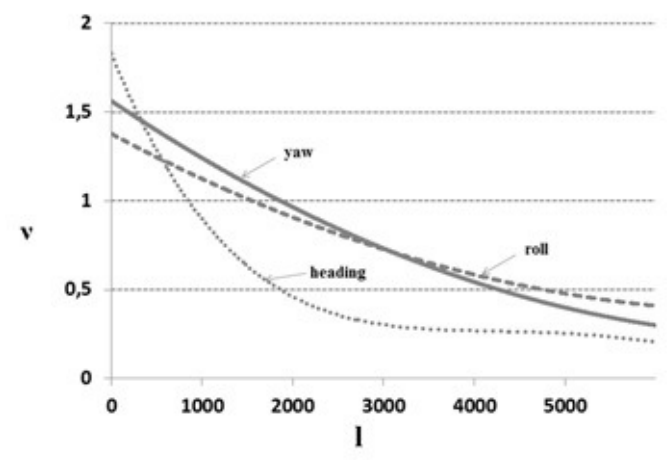

Fig. 3. The calculation of initial alignment algorithm step 


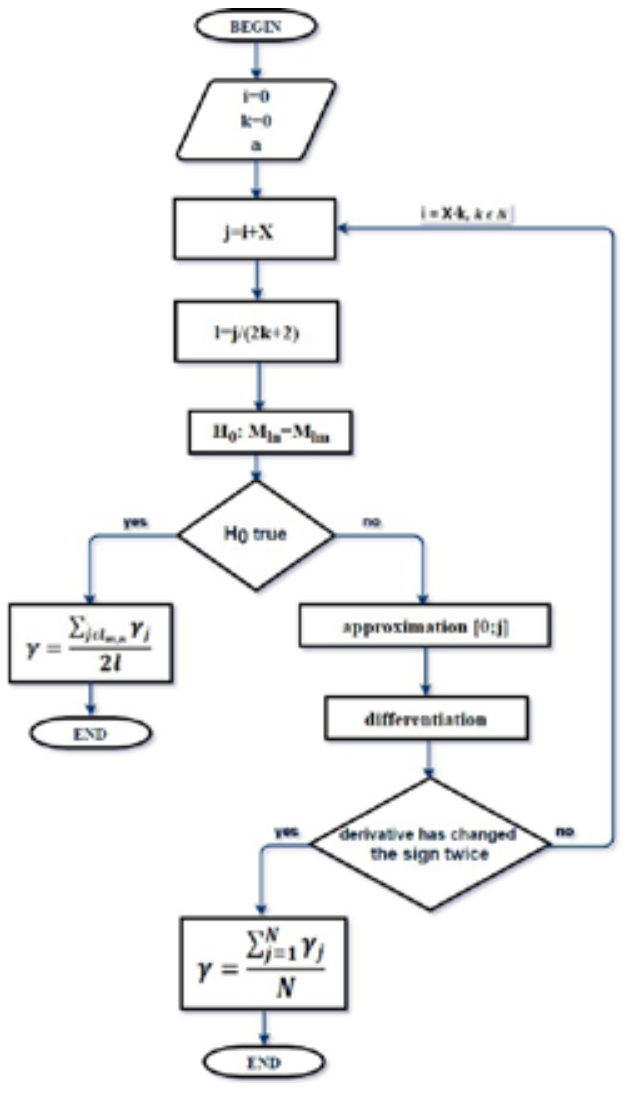

Fig. 4. Flow chart of ANR initial alignment algorithm

The period of the slowly varying component of the error is determined by the analysis of a derivative of measured ANR angle values as within the period of the slowly varying component of the error the derivative of input data changes its sign two times.

Flow chart of the developed algorithm of initial alignment is represented in Fig. 4.

In Fig. 4:

$\alpha$-type 1 error probability (prior specified);

$\mathrm{X}$ - algorithm step (minimum number of attitude angle measurements);

$\mathrm{H}_{0}$ - hypothesis on equality of two samples parts each with $l$ length;

$1=\mathrm{X} / 2$;

$\mathrm{M}-$ mean value of samples;

$\mathrm{n}, \mathrm{m}$ - sample order number;

$\mathrm{N}$ - number of measurements of an angle between two derivative symbol changing;

$\gamma-$ attitude angle value under determination.

\section{Experimental results}

The developed algorithm of ANR initial alignment was tested in the course of initial alignment of ANR measuring axes relative to construction axes of the object on site. The results of approbation are represented in Table 1. 
Table 1. The results of the developed method approbation

\begin{tabular}{|c|c|c|c|c|c|c|c|}
\hline \multirow[b]{2}{*}{ № } & \multirow{2}{*}{$\begin{array}{c}\text { Real angle } \\
\text { value, } \\
\text { degree }\end{array}$} & \multicolumn{2}{|c|}{$\begin{array}{l}\text { Measured angle } \\
\text { value, degree }\end{array}$} & \multirow{2}{*}{$\begin{array}{l}\text { The difference of } \\
\text { systematic corrections } \\
\text { to measured angle } \\
\text { value obtained by } \\
\text { existing and by } \\
\text { developed methods }\end{array}$} & \multirow{2}{*}{$\begin{array}{c}\text { Time of } \\
\text { measuring } \\
\text { by existing } \\
\text { method, s }\end{array}$} & \multirow{2}{*}{$\begin{array}{c}\text { Time of } \\
\text { measuring } \\
\text { by developed } \\
\text { method, s }\end{array}$} & \multirow{2}{*}{$\begin{array}{c}\text { Reduced } \\
\text { measuring } \\
\text { time }\end{array}$} \\
\hline & & $\begin{array}{l}\text { by } \\
\text { existing } \\
\text { method }\end{array}$ & $\begin{array}{c}\text { by } \\
\text { developed } \\
\text { method }\end{array}$ & & & & \\
\hline \multicolumn{8}{|c|}{ Course angle } \\
\hline 1 & 157,3521 & 172,0357 & 172,0426 & $-0,417$ & 1800 & 4000 & By 4,5 times \\
\hline 2 & 157,3527 & 172,0331 & 172,0426 & $-0,5735$ & 1800 & 4000 & By 4,5 times \\
\hline 3 & 263,0027 & 262,9794 & 262,9621 & 1,0395 & 1800 & 4000 & By 4,5 times \\
\hline \multicolumn{8}{|c|}{ Roll angle } \\
\hline 1 & $-0,6603$ & $-0,7925$ & $-0,8132$ & 1,2386 & 1800 & 8000 & By 2,2 times \\
\hline 2 & $-0,6583$ & $-0,8097$ & $-0,8247$ & 0,9033 & 1800 & 8000 & By 2,2 times \\
\hline 3 & $-0,0811$ & $-0,2386$ & $-0,2425$ & 0,2381 & 1800 & 8000 & By 2,2 times \\
\hline \multicolumn{8}{|c|}{ Pitch angle } \\
\hline 1 & $-0,2603$ & 0,1674 & 0,1808 & $-0,8076$ & 1800 & 3000 & By 6 times \\
\hline 2 & $-0,2576$ & 0,1638 & 0,1808 & $-1,0224$ & 1800 & 3000 & By 6 times \\
\hline 3 & $-0,2449$ & 0,8919 & 0,8937 & $-0,1099$ & 1800 & 6000 & By 3 times \\
\hline
\end{tabular}

\section{Discussion of results}

According to Table 1 there was a series of three experiments of ANR initial alignments on the object on site each experiment $5 \mathrm{~h}$ long (the demands of the existing ANR initial alignment method), the time of initial alignment performed by the developed method was reduced from 2,2 times to 6 times. Moreover the difference between systematic corrections and measured attitude angles values does not exceed $20 \%$ of ANR bias.

\section{Conclusion}

Thus, in the course of performed researches the new method of defining the systematic corrections for ANR attitude angles measurement with the initial alignments on the customer object. ANR initial alignment carried out by the developed method is not less than $50 \%$ faster than by existing methods.

\section{References}

[1] Alirshin B., Veremeenko K., Chernomorsky A. Orientation and navigation of mobile objects: modern information technologies. M.: FIZMATLIT, 2006, 424 p. (in Russian).

[2] Emelyancev G., Dranitsyna E., Blazhnov B. Test bed calibration of FOG-based strapdown inertial measurement unit. Scientific and technical journal "Gyroskopiya i Navigatsiya", 2012, 3(78), 55-63 (in Russian).

[3] Mohammed El-Diasty, Spiros Pagiatakis. Calibration and Stochastic Modelling of Inertial Navigation Sensor Errors, Journal of Global Positioning Systems, 2008, 7 (2), 170-182.

[4] Parusnikov N. The task of calibrating a non-carded inertial navigation system at orthogonal frame. Proceedings of the Russian Academy of Sciences. Mechanics of solids. 2009, (4), 3-6 (in Russian). 
[5] Alirshin B., Antonov D., Veremeenko K., Zharkov M. Strongly coupled multi-antenna integrated inertial-satellite navigation system, Electronic Journal «Trudy MAI», 54, 14-17 (in Russian).

[6] Borsoev V., Grebennikov A., Desyatov A. Integration GLONASS/GPS attitude reference receivers with INS on aircrafts. Scientific Bulletin of MSTUCA. Radiophysics and Radio Engineering Series, 2009, 139, $91-95$ (in Russian).

[7] Shebshaevich V., Dmitriev P., Ivancevich N. and other; edited by V. Shebshaevich. Network satellite radio navigation systems. 2-nd edition, Mocow, Radio and svyaz, 1993, 408 p. (in Russian). 